\title{
O Brincar Simbólico e a Organização Narrativa da Experiência de Vida na Criança
}

\section{Symbolic Play and the Narrative Organization of the Child's Life Experience}

\author{
André Guirland Vieira**a \&Tania Mara Sperb*b \\ ${ }^{a}$ Universidade Luterana do Brasil, Canoas, Brasil, ${ }^{b}$ Universidade Federal do Rio Grande do Sul, Porto Alegre, Brasil
}

\begin{abstract}
Resumo
O presente trabalho estuda a narrativa e a imagem como elementos da linguagem do brincar simbólico. Para isto, uma criança foi acompanhada em um processo de psicoterapia por um período aproximado de um ano. $\mathrm{O}$ brincar simbólico da criança na caixa de areia - sandplay - foi analisado em termos da organização narrativa e da construção de significado a partir da teoria e do método de Psicologia Analítica de C. G. Jung e da teoria narrativa de J. Bruner. Nosso estudo demonstra que o brincar simbólico é uma forma de linguagem e que através dele a criança constrói um texto o qual apresenta-se como uma narrativa ou como uma imagem; que este texto está repleto de elementos os quais aparecem como outras narrativas ou imagens que se interpõem às narrativas construídas pela criança. Mostra que a criança organiza a sua experiência do mundo e a sua experiência da vida através deste texto. Mostra também que as narrativas produzidas através do brincar simbólico da criança possuem uma relação com as narrativas produzidas ao longo da história cultural da humanidade. Finalmente, indica que o brincar simbólico tem uma função cognitiva de organizar a experiência de vida da criança.

Palavras-chave: Narrativa; imagem; brincar simbólico; Psicologia Analítica; caixa de areia.

Abstract

The present work studies the narrative and the image as elements of the language of symbolic play. With this objective a child was observed during approximately one year while in a psychotherapeutic process. The child's symbolic play in the sandplay was analyzed concerning narrative organization and construction of meaning based on Jung's Analytical Psychology theory and method, and Bruner's narrative theory. The study shows that symbolic play is a form of language, and through it the child constructs a text that presents itself as a narrative or as an image; that this text is filled with cultural elements which show themselves as new narratives or images that mix with the ones the child had constructed. Also, it shows that the child organizes his/her life experience and that of the world by means of this text; that the narratives produced by symbolic play are similar to those produced by the cultural history of mankind; and, finally, that symbolic play has a cognitive function of organizing the child's life experience.

Keywords: Narrative; image; symbolic play; Analytical Psychology; sandplay.
\end{abstract}

\section{Narrativa}

Para Bruner (1986/1997), os seres humanos constroem significado a partir dos sistemas simbólicos já dados na cultura. Estes sistemas simbólicos constituem uma espécie de kit de ferramentas que os homens utilizam para construir suas representações do mundo. A narrativa é uma dessas ferramentas: "filosoficamente falando, meu ponto de vista em relação à narrativa é construtivista - uma visão que tem como premissa que a principal função da mente é a 'construção do mundo', quer seja através das ciências ou das artes” (Bruner, 1986/1987, p. 11). A idéia da narrativa

* Endereço para correspondência: André Guirland Vieira/ Prof ${ }^{\mathrm{a}}$. Dr ${ }^{\mathrm{a}}$ Tânia Mara Sperb, Universidade Federal do Rio Grande do Sul, Instituto de Psicologia, Departamento de Psicologia do Desenvolvimento e da Personalidade, Rua Ramiro Barcelos, 2600, Santana, Porto Alegre, RS, 90035-003. Fone: (51) 3308-5246; Fax: (51)3308-5473. E-mail: agv65@ibest.com.br e sperbt@terra.com.br

Atualmente o autor desenvolve atividades na Universidade Luterana do Brasil (ULBRA) - São Jerônimo - RS, e no Centro de Psicologia Analítica.

O presente artigo integra o corpo de tese de doutorado do autor, defendida em 2003, no Instituto de Psicologia da Universidade Federal do Rio Grande do Sul (UFRGS) e escrita com financiamento do CNPq. como importante ferramenta na construção da representação do mundo parte da concepção de Kant (1781/1985) de que, enquanto o espaço é a forma de nossa experiência exterior, o tempo é a forma de nossa experiência interior. Além de Kant, Bruner toma Ricoeur (1983/1994) que, em Tempo e Narrativa, propõe que a representação humana do tempo e, particularmente a experiência do tempo vivido, só pode se dar na forma de uma narrativa. A partir daí, Bruner (1986/1987) irá postular duas teses.

A primeira tese é a seguinte: nós não temos outra maneira de descrever o tempo vivido a não ser na forma de uma narrativa. ... Minha segunda tese é a de que a mimesis entre o que chamamos de vida e a narrativa é uma via de mão dupla: isto é, assim como a arte imita a vida, no sentido de Aristóteles, assim, como propõe Oscar Wilde, a vida imita a arte. Narrativa imita a vida, vida imita a narrativa. 'Vida', neste sentido, é o mesmo tipo de construção da imaginação humana do que a narrativa. Ela é construída pelos seres humanos a partir de um raciocínio ativo, através do mesmo tipo de raciocínio a partir do qual nós construímos as narrativas (p. 12-13). 
A representação de nossa experiência de vida é, portanto, uma narrativa, e nós utilizamos a narrativa como uma ferramenta, a fim de organizar nosso contato com o mundo em termos de uma experiência inteligível.

O coração do meu argumento é o seguinte: eventualmente os processos lingüísticos e cognitivos moldados culturalmente que guiam a autoprodução das narrativas de vida assumem o poder de estruturar a experiência perceptiva, de organizar a memória, de segmentar ou unir os diversos eventos de uma vida. No final, nós nos tornamos as narrativas autobiográficas através das quais nós contamos nossas vidas. E dado à conformação cultural a qual eu referi, nós também nos tornamos variantes das formas culturais canônicas (p. 15).

A forma de organização da experiência a partir da narrativa é, entretanto, diferente de uma forma de organização lógica ou baseada em categorias lógicas. Bruner (1986/ 1997) propõe a coexistência, no homem, de duas formas de pensamento: o pensamento lógico-científico ou paradigmático e o pensamento narrativo. Estas duas formas de pensamento correspondem a dois modos de funcionamento cognitivo distintos e complementares, cada um fornecendo diferentes modos de ordenamento da experiência e de construção da realidade. Os dois são irredutíveis um ao outro. O pensamento lógico (Bruner prefere o termo paradigmático) comprova a realidade através de procedimentos direcionados para estabelecer provas formais e empíricas. O pensamento narrativo busca não a verdade, mas a verossimilhança. $\mathrm{O}$ primeiro leva à busca de verdades universais, o segundo de condições particulares prováveis entre dois eventos. O pensamento lógico-científico tenta construir um sistema formal e matemático de descrição e explicação. Ele emprega a categorização ou a conceituação e as operações pelas quais as categorias são estabelecidas, instanciadas, idealizadas e relacionadas umas às outras, a fim de formar um sistema.

Sua linguagem é regulada por necessidades de consistência e de não-contradição. Seu domínio é definido não apenas por elementos observáveis aos quais suas afirmações básicas se referem, mas também pelo conjunto de mundos possíveis que podem ser gerados logicamente e testados contra os elementos observáveis - ou seja, é conduzido por hipóteses fundamentadas (Bruner, 1986/1997, p. 14).

Por outro lado, o pensamento narrativo está vinculado à imaginação. Conduz à construção de histórias boas, dramas envolventes, relatos históricos críveis (embora não necessariamente verdadeiros). Ele trata de ações e intenções humanas e das vicissitudes que marcam seu curso. E é esse retrato da ação humana que aproxima a narrativa ao drama. A proposição da coexistência no homem de uma forma de pensamento lógico com uma forma de pensamento ligado à fantasia e à imaginação é também tratada por Jung (1912/1986). De forma muito semelhante a Bruner, Jung propõe que o pensamento fantasia é o responsável pela construção dos mitos e, portanto, das narrativas.

\section{Arquétipo}

A teoria dos arquétipos de C. G. Jung apresenta-se como fundamental no estabelecimento de uma relação entre o brincar simbólico da criança e a produção histórico-cultural da humanidade e, portanto, da cultura como elemento chave no entendimento do brincar simbólico como linguagem e sua interpretação. Encontramos, ao longo da obra de Jung, abordagens conceituais distintas de arquétipo; selecionamos, para o presente escrito, duas abordagens complementares. Arquétipo e instinto são, em primeiro lugar, conceitos muito próximos, e a suposição de que temos arquétipos é indissociável da que temos instintos. Jung (1919/1984a) define instinto como um pattern of behaviour (padrão de comportamento), de caráter compulsivo e inconsciente. O instinto é um impulso natural, cego e dirigido para certas ações, sem deliberação e, muito freqüentemente, sem uma representação na consciência. "Os instintos são forma típicas de comportamento, e todas as vezes que nos deparamos com formas de reação que se repetem de maneira uniforme e regular, tratase de um instinto, quer esteja associado a um motivo consciente ou não" (p. 139). O instinto encontra sua contraparte no arquétipo. $\mathrm{O}$ arquétipo, ou a imagem primordial, poderia ser descrita como a percepção do instinto de si mesmo ou como o auto-retrato do instinto. Há aqui uma semelhança entre o arquétipo e a consciência, na medida em que esta última é uma percepção interior do processo vital objetivo. Do mesmo modo que a apreensão consciente imprime forma e finalidade ao nosso comportamento, assim, a apreensão inconsciente determina a forma e a destinação do instinto através do arquétipo. Deste modo, Jung (1919/1984a) nos dá a seguinte definição de arquétipo: "Os arquétipos são formas de apreensão, e todas as vezes que nos deparamos com formas de apreensão que se repetem de maneira uniforme e regular, temos diante de nós um arquétipo, quer reconheçamos ou não o seu caráter mitológico" (p. 141). É, entretanto, impossível dizer o que vem em primeiro lugar, se a apreensão ou o impulso para agir. Assim, para Jung, instinto e arquétipo constituem uma só e mesma coisa, uma única atividade vital que temos de conceber como dois processos distintos a fim de termos uma compreensão melhor. Os instintos e os arquétipos constituem o que Jung chamou de inconsciente coletivo. Esta é uma abordagem conceitual que trata da natureza do arquétipo em relação ao instinto e aos processos fisiológicos do homem.

Uma segunda abordagem, parte da metodologia de investigação utilizada, por Jung (1940/1959), no estudo das fantasias da humanidade. Observando as formas do pensamento primitivo, da mitologia, bem como dos produtos do inconsciente, na forma de sonhos, fantasias, visões e delírios, Jung começou a reparar a presença de regularidades, isto é, de situações típicas ou de tipos. Há tipos de situações e figuras que se repetem freqüentemente e que se organizam em torno de um sentido correspondente. Jung passou a designar estas repetições como "motivos", salientando que não existem apenas sonhos típicos, mas também motivos típicos nos sonhos. A esses motivos típicos, Jung deu o nome de Arquétipos. 
Críticos têm se contentado em afirmar que tais arquétipos não existem. Certamente eles não existem, não mais do que existe um sistema botânico na natureza! Mas será que por isso vamos negar a existência de famílias de plantas naturais? Ou será que vamos contestar a ocorrência e contínua repetição de certas semelhanças morfológicas e funcionais? Com as formas típicas do inconsciente, trata-se de algo a princípio muito semelhante. São formas existentes a priori ou normas biológicas da atividade anímica. (p. 183).

Assim, os arquétipos são, em um primeiro momento, uma tipologia, uma observação de regularidades na produção do espírito humano, e entenda-se espírito aqui como toda produção de texto: sonhos, fantasias, delírios, obras de arte, enfim, de toda produção cultural do homem. E é justamente por isso que a compreensão da história cultural se faz tão necessária ao pesquisador e ao psicoterapeuta, sem ela torna-se impossível o entendimento da produção humana, seja ela a produção do artista, do sujeito de pesquisa ou a do paciente. Sem a comparação histórico-cultural perde-se a possibilidade de observação desses tipos, que, desta forma, passariam despercebidos por nós, e da reflexão sobre o seu significado, tanto para a humanidade como um todo, como para o indivíduo que o atualiza em sua produção.

\section{Brincar na Caixa de Areia}

A situação de brincar escolhida para o presente trabalho foi a do brincar simbólico na caixa de areia - Sandplay - tal como proposto por Dora Kalff (1980). A Caixa de Areia (Sandplay) é uma técnica desenvolvida no âmbito da Psicologia Analítica para o trabalho com crianças. Consiste em oferecer à criança uma pequena caixa de areia de dimensões iguais a 72 X 50 X 7,5 cm juntamente com uma série de brinquedos. Foram utilizados brinquedos estruturados na forma de uma série de miniaturas, representando animais selvagens e domésticos, peixes, aves, conchas, pedras, carros, barcos, aviões, pontes, casas, árvores e figuras humanas de diversos tipos e em diversas situações. Nenhuma instrução foi dada à criança, ela foi simplesmente encorajada a brincar na caixa de areia. $\mathrm{O}$ brincar da criança foi registrado em fotografias feitas a cada momento em que um cenário foi construído ou em que uma ação foi concluída. Não foi feita nenhuma interpretação do simbolismo do brincar para a criança, deixando que ela brincasse livremente. Não foi feito nenhum direcionamento do brincar da criança, embora o terapeuta tenha participado do brincar junto a ela. As sessões tinham duração de uma hora e freqüência de um encontro por semana, as quais se estenderam por treze meses.

As sessões com a criança, nas quais foram produzidas situações de brincar na caixa de areia, além de fotografadas, foram relatadas em um diário clínico. As sessões, nas quais não houve produção de brincar simbólico não foram anotadas. Foram também anotados no diário clínico as entrevistas com os pais ou responsáveis, as impressões do psicoterapeuta/pesquisador sobre a criança ou a família e interpretações. As anotações no diário clínico foram feitas ao final de cada sessão com a criança ou com os pais.
As anotações tinham o objetivo de reconstituir as estórias encenadas na caixa de areia ou, no caso das entrevistas com os pais, registrar dados históricos da criança ou da família.

Em nosso trabalho, utilizamos um modelo de estudo de caso clínico. Foram feitos, a princípio, três estudos de caso com crianças entre seis e oito anos de idade, dos quais foi selecionado um para apresentação no presente artigo. O brincar simbólico das crianças foi estudado em um contexto de psicoterapia por aproximadamente um ano. A importância do contex to de psicoterapia para a pesquisa deveu-se à observação da riqueza do material simbólico produzido pela criança em uma situação em que há demanda de tratamento psicoterápico. A demanda de psicoterapia corresponde a um motivo para falar. Aqui a palavra demanda assume o sentido da falta que dá início a uma busca, tal como encontramos no processo narrativo, por exemplo, as estórias da demanda (busca) do Graal. E é essa mesma falta e busca de algo perdido ou a ser restaurado que move tanto o processo terapêutico como o da produção simbólica do homem e da criança. A forma de pesquisa em contexto de psicoterapia caracterizou, portanto, nosso estudo como longitudinal. As crianças participantes do estudo foram selecionadas a partir de um trabalho em um ambulatório de atendimento psicológico. Utilizamos, segundo o modelo de estudo de caso proposto por Yin (1994), um delineamento de estudos de casos múltiplos - três estudos de caso. Em cada caso, foram comparadas a produção simbólica no brincar e a situação de vida e familiar, tal como trazida através de entrevistas com os pais ou responsáveis.

Os dados obtidos foram interpretados à luz da Psicologia Analítica de C. G. Jung, tanto em termos da estrutura narrativa, como da interpretação psicológica propriamente dita. $\mathrm{Na}$ análise da estrutura narrativa utilizamos o esquema narrativo de C. G. Jung (1945/1984c), o qual divide a narrativa em quatro partes ou macroproposições: Exposição, na qual são apresentados a situação inicial da estória, o lugar, o tempo e os personagens; Desenvolvimento, na qual a situação inicial complica-se, estabelecendo uma tensão, porque não se sabe o que vai acontecer; Culminação ou $P e-$ ripécia, na qual acontece alguma coisa de decisivo, ou a situação muda completamente; e a Solução ou Resultado, na qual o problema ou a falta resolve-se. Para a interpretação dos casos, seguimos, igualmente, os passos prescritos por C. G. Jung (1928/1984b). São estes: a reconstituição do contexto do brincar e, quando necessário, a amplificação. $\mathrm{Na}$ reconstituição do contexto, observamos as associações da criança com o brincar na forma do contar sobre o que ela construiu, fala esta que nos foi indispensável para a elaboração das estórias ou das cenas transcritas. Observamos, também, a série de situações de brincar na caixa de areia. A partir do estudo da série, isolamos os motivos recorrentes e suas variações. Consideramos cada motivo como uma narrativa independente, como uma estória e suas variações. O último passo da contextualização, a comparação do brincar com situação atual da consciência (que pode ser também descrita como a posição do sujeito em relação à situação atual de vida e familiar), encaminha a interpretação 
propriamente dita. Quando necessário, este último passo foi enriquecido com associações do terapeuta com base no seu conhecimento do sentido dos elementos do brincar, tais como representados por narrativas e mitos dados na cultura, que Jung (1928/1984b) chamou de amplificação.

\section{Carlos': Organizando a Experiência da Violência Familiar}

Carlos foi trazido à psicoterapia pela mãe em março de 2001, quando contava com seis anos e dois meses. Nesta ocasião, a mãe relatou que o motivo da consulta foi o fato de Carlos apresentar o que ela chamou de "nervosismo", o qual tinha, segundo ela, se tornado mais intenso ao longo dos últimos dois anos. Não identificou nem um fato ou situação especial que tenha marcado o início desse "nervosismo", mas passou a relatar a história de um casamento extremamente violento. Contou que o marido costumava beber e, quando bêbado, tentava agredir ela e as crianças. Ela, por sua vez, revidava com igual violência, de maneira que não era pouco comum os dois "chegarem às vias de fato", agredindo-se mutuamente. A história de brigas intensas tem se repetido ao longo de pelo menos onze anos de casamento. Mas tal situação sofreu uma piora nos últimos três anos, com o desemprego do marido e o decorrente aumento do consumo de álcool. Desde então, a mãe tem sustentado a casa. Contou que o pai de Carlos é viúvo do casamento anterior e que assassinou a ex-esposa grávida e com um filho pequeno. Segundo a mãe, ele a ameaçava de morte repetidamente e chegou a ameaçá-la com um revólver carregado, mas ela sempre enfrentou-o nestas situações. Relatou que as crianças, Carlos, Simone e um irmão mais velho, adolescente e filho daquele primeiro casamento, sempre assistiam às brigas. Contou que Carlos começou a freqüentar a primeira série, mas que foi desligado pela pouca idade e por apresentar uma fala imatura. De fato, quando conheci Carlos, ele aparentava ser um menino franzino, mas muito vivaz e curioso, mostrava-se também muito infantil. Não conseguiu ficar na sala de espera enquanto eu conversava com a mãe, tendo insistido para ficar junto a ela. Sugeri, então, que ele brincasse, e ele ficou explorando os brinquedos e me perguntando o que cada animal comia e quem era mais forte do que quem. Sua linguagem era de difícil compreensão, devido a uma pronúncia demasiadamente infantil. A mãe contou que Carlos gostava muito de animais, e não vi sinais de que fosse cruel com eles. Chamou-me a atenção o fato de a mãe tratar Carlos verbalmente por "bebê". Relatou, também, que o menino teve, no passado, episódios de asma alérgica e de febres altas seguidas de convulsões. Contou que fez tratamento com neurologista, mas não soube dizer que medicamentos tomou. Teve alta do tratamento e, no momento das entrevistas iniciais, não fazia uso de nenhum tipo de medicação.

Em sua primeira sessão, Carlos dedicou a maior parte do tempo para explorar os brinquedos. Ensaiou, também algumas rápidas estórias. Na primeira, colocou na caixa de areia um leão pai e um leão filho, um elefante pai e um elefante

${ }^{1} \mathrm{O}$ nome citado é fictício. filho. Então apareceu um tigre que matou o filhote do leão e, como conseqüência disso, o tigre e o leão brigaram. Em uma segunda estória, os animais foram postos em jaulas. No centro da caixa foi posto o tigre. À esquerda deste, uma zebra e uma girafa e, à direita, dois filhotes de leão. Carlos, então, tirou as jaulas. Apareceu um caranguejo (siri) e matou os filhotes do leão. O caranguejo, então, mordeu a girafa e foi morto pela zebra.

Na segunda sessão, Carlos montou um zoológico na caixa de areia. À esquerda da caixa colocou um leão, depois um tigre. À direita, colocou uma zebra e um elefante. Todos foram postos em jaulas individuais, de modo que apenas a jaula do elefante possuísse uma abertura que lhe permitisse sair.

$\mathrm{Na}$ terceira sessão encenou a seguinte brincadeira: colocou vários animais na caixa de areia, leão, tigre, rinoceronte, zebra, girafa, gorila e mais alguns outros, todos em jaulas individuais. Depois retirou as jaulas, soltando todos os animais. Carlos disse, então, que era um vendedor de animais, e eu um comprador. Vendeu-me todos os animais, os quais foram colocados em jaulas no chão, ao pé da caixa de areia.

A brincadeira de Carlos me vender os animais continuou na sessão seguinte. Ele primeiro colocou na caixa de areia vários animais: leão, tigre, dois elefantes, hipopótamo, zebra, gorila, dois veados, cabra, burro e girafa. Anunciou, então, que a caixa era a casa dele e que ele iria me vender os bichos. Estes, após a compra, foram cuidadosamente colocados em jaulas dispostas no chão, agrupados de maneira a um não fazer mal uns aos outros. Carlos, então, me falou que o elefante grande era "brabo", e que o elefante pequeno era "manso", que o grande era o pai e o pequeno o filho. Nas jaulas, o elefante grande está junto com o tigre, enquanto que o pequeno está na mesma jaula da girafa. De modo similar ao elefante, o veado grande era brabo, enquanto que o pequeno era manso. $\mathrm{O}$ grande era o pai e o pequeno, o filho. Depois disso, nós dois juntos colocamos todos os animais dentro de uma grande jaula. Carlos, então, comentou que, para ele, todos os animais eram brabos, e que por isso todos tinham de ser colocados dentro de uma jaula. A brincadeira sofreu, então, uma mudança radical de rumo. Carlos construiu um cenário composto por uma casa (representada por uma miniatura de igreja), uma ponte e cinco peixes. Nós passamos a pescar os peixes, que estavam sob a ponte, e a levá-los para a casa, que, neste momento, passou a ser a sua casa. Finalmente, ele construiu um cercado junto à ponte e colocou, ali, os peixes.

Nas estórias e cenas tecidas por Carlos, temos a peculiaridade de que os personagens são animais, o que nos coloca a necessidade, para compreendê-las, de termos não apenas de suas associações imediatas, mas também de um conhecimento prévio sobre os sentidos culturalmente atribuídos a estes animais, até porque, como veremos, suas associações não aparecem descoladas desse sentido cultural, mas se unem e se acrescentam a ele. A presença de animais em narrativas é muito antiga e difundida no mundo todo e, apesar das variações de sentido atribuídas a cada animal, é 
possível circunscrever alguns mais ou menos universais. É particularmente interessante, para nós, este diálogo entre as associações pessoais e as associações culturais com os elementos simbólicos do brincar, porque este diálogo se dá na forma de um cruzamento de narrativas. De um lado, temos as narrativas construídas pela criança no brincar e, por outro, temos aquelas estórias escritas ao longo da história da cultura humana.

Observando as narrativas produzidas por Carlos, podemos identificar, desde a primeira sessão até aqui, a construção de uma primeira série, a qual apresenta o desenvolvimento de um primeiro motivo. Uma série pode ser definida como uma seqüência de estórias ou narrativas que giram em torno de um tema ou motivo (história/fábula) comum. Em uma série, as narrativas não necessariamente se repetem, mas se complementam e se enriquecem. Nesta série, temos um grupo de personagens que aparecem nas várias narrativas e em situações diferentes. São eles, o leão, o tigre, o elefante, a zebra, a girafa e o veado. Mas a série define-se não apenas pela repetição de personagens animais, mas também pelas figuras do pai e do filho, personagens centrais do motivo que, por assim dizer, organiza a série: a ameaça ao filho, ou a ameaça do pai ao filho.

Do mesmo modo que Jung (1947/1987), quem propõe que os sonhos iniciais de uma psicoterapia tem um valor diagnóstico, na medida em que retratam, de forma simbólica, o problema atual do paciente, podemos pensar no valor diagnóstico das primeiras situações de brincar produzidas pela criança. Não é difícil ver, comparando as narrativas de Carlos com a história e a situação familiar trazidas na entrevista inicial com a mãe, que seu principal problema gira em torno da violência do pai, e de como ele, Carlos, vai lidar com isto. Na primeira sessão, produz duas narrativas, na primeira aparecem um leão pai e seu filhote e um elefante pai e seu filhote - Exposição, então surge um tigre - Desenvolvimento - que mata o filhote do leão - Culminação/Peripécia, então leão e tigre brigam - Solução. Na segunda narrativa os animais (girafa, zebra, tigre e filhotes de leão) estão enjaulados - Exposição, então as jaulas são retiradas e aparece um caranguejo Desenvolvimento. O caranguejo mata os filhotes do leão e morde a girafa - Culminação/Peripécia, mas é, finalmente, morto pela zebra - Solução. Nestas estórias, o pai aparece como um leão e como um elefante, animais que, para Carlos, representam a força, o poder e a ferocidade. Aqui, não é diretamente o leão que ataca e mata os seus filhos, mas um outro animal feroz e exterior ao mundo do pai e do filho: o tigre. É como se Carlos não identificasse ou não pudesse identificar, neste primeiro momento, a ameaça ou o sentimento de ameaça diretamente ao pai, por isso substitui o pai leão pelo tigre. A situação psicológica de Carlos é a de alguém que está angustiado e com medo de uma determinada situação a qual ele não consegue identificar ou definir. O esclarecimento da situação virá somente mais tarde, e, com ele, uma mudança de atitude. Entretanto, não é apenas o tigre que representa uma ameaça, mas também o caranguejo, e desta vez aos filhos. Este aparece como uma figura obscura na estória, Carlos pouco fala do caranguejo.
Ao amplificarmos o símbolo, veremos, de acordo com Chevalier e Gheerbrant (1990), que, tanto no ocidente como no oriente, o caranguejo é comumente associado à água e à lua. Enquanto signo de Câncer, o caranguejo está relacionado à lua, à água, ao feminino e ao materno. Tal amplificação nos fez pensar que o perigo talvez não viesse exclusivamente do pai, mas também da mãe, hipótese confirmada mais adiante, no decorrer do caso.

A Segunda narrativa dá seguimento à série, continuando esta primeira estória, mas não na forma de uma narrativa e sim na de uma imagem, na de uma única cena. Nela, Carlos separa em jaulas distintas o leão, o tigre, a zebra e o elefante. Fala que somente o elefante pode ter sua jaula aberta. Além do fato de que os animais aparecem aqui controlados, Carlos nos propõe nesta cena uma diferença entre o pai leão e o pai elefante. $O$ pai leão tem de ficar preso, tal como o tigre, mas ao pai elefante é dada a possibilidade de liberdade. Cabe, então, procurarmos traçar algumas diferenças entre o símbolo do leão e o do elefante. Segundo Chevalier e Gheerbrant (1990), tanto o leão como o elefante são associados em diversas culturas ao redor do mundo ao poder, à realeza, à sabedoria e à justiça, com a diferença de que ao leão é também associado à cobiça, à tirania, à soberba e ao desejo de poder, o leão é aquele que não consegue dominar a ira. Enquanto o reinado sob o símbolo do leão está sujeito à coerção e à tirania, o sob o símbolo do elefante é associado à estabilidade e à paz. Na Índia e no Tibete, o elefante é o animal suporte do mundo. O universo repousa sobre o lombo de um elefante, assim como uma esfera sobre quatro pilastras. Na Índia, o elefante ainda lembra Ganeça, o deus hindu da ciência, das letras, símbolo do conhecimento, o qual tem a cabeça de um elefante. Podemos sintetizar estas diferenças propondo que enquanto o pai leão pode ser um tirano violento, orgulhoso e sedento de poder, o pai elefante, embora igualmente forte e poderoso, é mais equilibrado e pacífico.

Carlos dá continuidade à série propondo uma brincadeira, na qual ele me vende os animais. Somos eu e ele, desta forma, incluídos na narrativa como personagens. Esta narrativa aparece organizada do seguinte modo: os animais estão em jaulas individuais - Exposição, então as jaulas são retiradas e os animais são soltos - Desenvolvimento. Então Carlos torna-se um vendedor de animais e eu um comprador. Ele me vende os animais - Culminação/Peripécia, os quais, após a venda, são colocados em jaulas ao pé da caixa de areia - Solução. A série continua na seguinte narrativa, os animais estão soltos em sua casa - Exposição, então ele me vende os bichos, que são colocados em jaulas que separam pai e filho de maneira que os pais não façam mal aos filhos - Desenvolvimento. Então todos os animais passam a ser brabos - Culminação/Peripécia - e, por isso, podem ser colocados juntos - Solução. É interessante notar que há um desenvolvimento da estória ao longo da série, o que fica mais claro quando analisamos as duas últimas narrativas. Aqui a estória é praticamente a mesma, mas com um ponto culminante e uma solução diferente. Como veremos um pouco adiante, o próprio ponto da narrativa em que ocorre 
a transformação na estória, isto é a Peripécia, indica o tipo de mudança de atitude de Carlos em relação ao pai e encaminha a solução, ao menos temporária do conflito: como todos os animais são, agora, brabos, pai e filho podem ficar juntos, ou se eu for brabo como meu pai poderei estar junto a ele e, portanto ser como ele. Pois se Carlos for brabo como o pai, poderá estabelecer com ele uma relação de igualdade que lhe possibilite romper com o estado anterior de submissão imposta pelo medo. Há, entretanto, uma segunda transformação dada por uma troca de personagens na narrativa: o pai leão sai de cena, dando lugar ao pai veado. Carlos não nos fala nada dessa transformação, mas se amplificarmos o símbolo do veado, veremos que ele é, no mínimo um animal menos colérico do que o leão. Partindo de Chevalier e Gheerbrant (1990) constatamos que, tanto na mitologia dos índios americanos como na iconografia cristã, o veado aparece associado à árvore. Sua galhada é como uma árvore que se renova perpetuamente, e é nela que Cristo aparece algumas vezes crucificado. Por preferir a solidão, ao veado são associadas as características da timidez, da melancolia, mas também da ousadia. No oriente o veado é um dos símbolos de Buda, do Bodhisattva que salva os homens do desespero, acalmando suas paixões. Isto é, enquanto o leão é associado às paixões desmedidas, particularmente à paixão ao poder, o veado é associado a um aprazamento das paixões. Podemos, portanto, pensar a transformação do leão em veado como um abrandamento do aspecto colérico e autoritário do leão, seja porque houve uma transformação do posicionamento do pai em relação ao filho, ou vice-versa. Por isso, quando fala que todos os animais são "brabos" e, por isso, podem ficar juntos, Carlos não está referindo-se à "brabeza" do leão, mas a uma mais controlada, como a do veado ou a do elefante. Isto reforça a hipótese de que Carlos já não se sente tão ameaçado pela violência do pai, e que está encontrando um meio de lidar com ela, o que parece se confirmar no fato de que a presente narrativa atua como uma conclusão de toda a série. A mudança radical de tema nas próximas brincadeiras/narrativas parece atestar em favor disso, é como se um conflito fosse, de fato, solucionado, permitindo que se possa pensar em outros temas.

Na sessão seguinte, Carlos deu continuidade à brincadeira com os peixes. Montou na caixa de areia um cenário em que se via uma casa (igreja) e um cercado que envolvia uma ponte e quatro peixes. Acrescentou um peixe espada e me pediu para pescá-lo. Eu o pesquei, e ele colocou o peixe ao lado da casa. Pesquei outro peixe, que ele colocou novamente ao lado da casa. Ele, por sua vez, pescou dois peixes. Nos alternamos na pescaria, e todos os peixes são colocados ao lado da casa.

Na sessão seguinte, Carlos chegou na sala perguntando se iríamos brincar de peixe. Montou na caixa de areia um cercado com uma ponte e sete peixes. Ao lado, colocou uma casa, a "sua casa”. Em seguida, iniciamos a brincadeira, pescamos alternadamente, eu e ele, os peixes e os colocamos ao lado da casa. Em entrevista com a mãe, ela relatou que Carlos estava mais maduro, passou, por iniciativa própria a dormir em um quarto só seu, antes ele dormia com a irmã mais velha ou com os pais. Contou que o quarto ficava distante do quarto dos pais, e que ele pedia, também, para apagar a luz. Passou a tomar banho sozinho e a se vestir sozinho. Começou a recusar roupas mais infantis, dizendo que queria se vestir como o pai. Carlos comentou com a mãe que agora era um "homem", que tinha de fazer as coisas por si e a cuidar de si. A mãe contou que, recentemente, Carlos acompanhou o pai em um trabalho de carregar um caminhão com tijolos, que trabalhou o tempo todo junto ao pai. Contou, também que Carlos gostava muito de animais e que andava muito afeiçoado a uma família de porcos e a uma de coelhos. Disse que ele adotou um cachorro de rua e que o estava treinando, contando que o cachorro fazia tudo que ele mandava. Ela também reparou que a fala de Carlos estava mais clara, que o falar como um bebê estava diminuindo, mas disse que ele pediu a ela para não me contar que ainda tomava mamadeira. A mãe, por sua vez, parecia estar conseguindo estimular as atitudes mais maduras do filho, como dormir em seu quarto, escolher suas roupas ou partilhar das atividades do pai.

Como pudemos observar através dos relatos das sessões subsequentes ao final da primeira série Carlos não apenas mudou o tema de suas estórias/brincadeiras, como também iniciou um processo de mudança de atitude em relação à vida. Ele, agora, já não admitia mais ser uma criancinha dependente da mãe, ele agora queria crescer. Este movimento apareceu a partir de uma identificação positiva com o pai. Ele, Carlos, queria, agora, ser um homem como o pai. Isto apareceu muito enfaticamente no relato da mãe nos vários momentos em que Carlos verbalizou que queria ser um homem, que queria se vestir como o pai, que tomava banho sozinho, como o pai, que dormia sozinho no quarto como um homem adulto ou quando trabalhava como o pai. Essas mudanças foram marcadas pela conclusão das narrativas sobre o pai ameaçador e pelo início da série de narrativas, cujo tema é a pescaria.

No brincar de pescar acentuou-se uma demanda de Carlos que já aparecia antes, na brincadeira em que ele me vendia os animais, qual seja, a de minha participação no brincar. No momento em que eu compro os animais ou em que pescamos juntos, eu passo a ter um papel ativo em sua brincadeira, eu passo a agir como um participante. Isto significa um aprofundamento da relação transferencial a partir da qual eu passo a participar ativamente em seu processo de transformação. Isto aparece em sua produção simbólica no momento em que, assim como ele, eu me torno um personagem de suas narrativas, e somos eu e ele que damos um rumo às estórias. Tanto é assim, que após a construção das narrativas sobre a pescaria, iniciamos um período longo em que apenas jogamos e conversamos. Se analisarmos, portanto, o que Carlos me vende ou o que pescamos, poderemos ter uma idéia do que está sendo transferido. O que ele me vende são os animais brabos ou selvagens, assim como o peixe que cabe a mim pescar é o peixe espada. Carlos transfere para mim, deste modo, a capacidade de lidar com os animais ferozes, ou traduzido em termos de sua situação de vida, a capacidade de lidar com o aspecto violento e hostil do pai. 
Isto ocorre a partir de um primeiro movimento, no qual os animais são retirados do seu mundo, dentro da caixa de areia, e transferidos ao meu mundo, fora da caixa de areia. $\mathrm{O}$ brincar de pescaria poderia ser visto como um retorno deste processo, no qual os animais retornam ao seu mundo e a sua casa dentro da caixa de areia. A pescaria seria, portanto, um símbolo do processo de integração, de conscientização e de retorno da solução antes transferida a mim $^{2}$. Tal interpretação encontra eco na amplificação do símbolo da pesca e do peixe tal como organizado em suas narrativas.

O esquema geral das narrativas da pescaria é o seguinte. Há uma situação inicial, na qual temos um cenário inicial composto por peixes na água, ponte e casa. Uma situação intermediária, na qual pescamos os peixes, e uma situação final, quando todos os peixes são pescados e colocados ao lado da casa. Uma narrativa mais completa aparece apenas na situação de brincar em que ele me pede para pescar um peixe espada. Ali aparecem, em um primeiro momento, uma casa, uma ponte, alguns peixes e uma cerca - Exposição. Carlos acrescenta um peixe espada e eu o pesco - Desenvolvimento. Depois disso, pescamos juntos - Culminação/Peripécia, até o momento em que todos os peixes são pescados Solução. Os elementos mais constantes da brincadeira são, além dos peixes, a casa (que é sempre figurada por uma igreja), a ponte e a cerca. Poderíamos pensar a ponte como um lugar de passagem, como um objeto que nos permite a passagem de um lugar a outro, de uma margem à outra. A travessia da água é um tema recorrente em diversas mitologias. No taoísmo a travessia da água simboliza uma mudança de visão de mundo ou uma mudança de atitude em relação ao mundo. A ponte também costuma aparecer como uma ligação entre o mundo sensível e o mundo supra-sensível, como a passagem entre a terra e o céu, o conhecido e o desconhecido ou, psicologicamente falando, entre a consciência e o inconsciente. Neste sentido, o arco-íris é uma ponte entre a terra e o Olimpo. O tema da ligação da consciência ao inconsciente aparece não só no símbolo da ponte, mas também no simbolismo da igreja e do peixe. A igreja enquanto templo é o espaço dessa ligação, é ela também uma ponte que liga o corriqueiro ao inefável, o conhecido ao desconhecido. O peixe, por sua vez, é o alimento das profundezas. Nos contos de Grimm (1853/1984), o peixe é aquele que recupera as cartas da princesa, perdidas no fundo do mar (ver o conto “Ferdinando fiel e Ferdinando infiel”). O peixe é, também, um príncipe encantado, que dá ao pescador grandes riquezas e poder de domínio sobre os homens e o universo, mas também os tira (ver o conto "Opescador e sua esposa”). O peixe é também um símbolo do deus e sacerdote que busca nas profundezas do oceano a sabedoria que alimenta os homens, tal como o deus-peixe Oanes da Babilônia, chamado também de “o revelador", ou Vishnu, que salva os Vedas na forma de peixe. Temos também os golfinhos, que para a antiguidade eram peixes e guias para os navegadores. Os golfinhos eram consagrados a Apolo, que tinha em

${ }^{2}$ Devo a compreensão do sentido da transferência à supervisão do caso.
Delfos (de delfim) o seu oráculo e o centro de seu culto. Neste sentido, Jung (1951/1982) identifica o ato de pescar a uma tentativa de apreender os conteúdos (peixes) do inconsciente.

As narrativas de Carlos sobre a pescaria podem ser lidas como um processo no qual ele tenta apreender o que antes era inconsciente para ele, isto é, o que antes estava projetado na transferência. Após a primeira narrativa desta série, Carlos começa a delimitar o espaço dos peixes com uma cerca. Esta delimitação pode ser vista como um símbolo de conscientização, pois no momento em que delimita uma parte do mar, ele passa a tornar esta parte um espaço relativamente pessoal. Carlos limita, assim, uma parcela do inconsciente, após o que ele busca trazer à consciência aquilo que foi delimitado (a pescaria). Podemos, portanto, pensar o período que inicia com a série de narrativas sobre a pescaria até o início da próxima série, como um momento de integração do inconsciente, de conscientização de sua situação pessoal diante da família, da escola, e do mundo e de uma mudança de atitude, de uma reorganização da vida em função dessa conscientização.

Na sessão em que Carlos iniciou uma nova série, contou um sonho, no qual um vampiro o pegava. Depois brincamos na caixa de areia. Ali, ele dispôs uma série de animais: zebra, gorila, rinoceronte, hipopótamo, veado, girafa, burro e cabra. Todos eles colocados em torno de duas árvores. À esquerda da caixa, uma casa (igreja) gradeada, "a casa do homem”. Então, nós dois caçamos os bichos. Carlos falou em um primeiro momento que matamos os animais, mas depois disse que eles foram "capados", o que para ele equivale a colocá-los em jaulas. Colocamos, assim, todos os animais em suas respectivas jaulas. Então todos os animais foram soltos, menos a girafa. Ela, então "matou” (o que para ele quer dizer feriu) todos os bichos, que, então, são levados de volta para as jaulas para serem cuidados. Então a girafa é morta, dando à luz um "filhotinho". Então, todos os animais têm filhotes "saídos da barriga". Finalmente, os animais adultos ficam presos e os filhotes soltos.

Na sessão seguinte, Carlos construiu duas estórias. Primeiro, dispôs na caixa de areia um grupo de animais, um tanque de guerra e um avião. Então, os soldados mataram todos os animais com o avião e o tanque. Depois, com uma faca, retiraram os filhotes da barriga deles, os quais foram postos em um cercado. Então os filhotes aumentaram em número e apareceram soltos na caixa. Os soldados levaram os filhotes em um caminhão para três cercados localizados fora da caixa. Depois disso, Carlos montou uma fazenda dentro da caixa com um casal de porcos e um filhote, uma vaca e seu filhote, um poço e um celeiro. Então os porcos foram "capados" (castrados).

Na próxima sessão, Carlos brincou novamente com os animais. Mães e filhos foram colocados na caixa de areia e, em seguida, mortos a tiros por nós. Na sessão seguinte, Carlos encenou, na caixa de areia, uma caçada de animais na floresta. Primeiro colocou as mães junto com seus filhotes, todos comendo das árvores. Então apareceram um carro e um tanque de guerra, dos quais saíram dois homens que mataram 
todas as mães. Depois disso, os homens laçaram os filhotes e os guardaram em carros para levá-los para o circo.

Na sessão seguinte, Carlos construiu na caixa de areia uma floresta com animais filhotes e adultos. Então, dois homens chegaram na floresta e mataram os animais. Depois, construiu, no chão, uma fazenda, na qual se via um cercado com vacas, um com porcos, um com um touro e um cavalo, um com uma porca e seu filhote e outro com um galo, uma galinha e um bezerro. Ao fundo via-se a cabana dos homens que mataram os animais na floresta e o carro e o avião que utilizaram para chegar à caixa. Carlos teve o cuidado de separar os machos das fêmeas porque "iriam brigar" ou porque "não dariam certo juntos".

Carlos apareceu muito disperso na próxima sessão. Fez várias tentativas de montar uma fazenda, por fim conseguiu, colocando vacas, touro, cavalo, porcos e uma galinha na caixa de areia. Ele iniciou, então, um processo de matar os animais. Mas o matar dele consistia em amarrá-los e levá-los para fora da caixa. Ele elegeu um cantinho embaixo da minha mesa, no qual ele colocou todos os animais juntos. Primeiro foi o touro, depois, as vacas e, finalmente os porcos.

Na sessão seguinte, Carlos montou um zoológico na caixa de areia. Escolheu cuidadosamente os animais pequenos e os colocou em um único cercado. Então apareceram dois homens (ele e eu) que abriram a porteira para que os elefantes saíssem do cercado.

Esta última série inicia com um sonho, Carlos sonha que é pego por um vampiro. Após conseguir assumir uma postura em relação ao pai que lhe permitisse vencer o medo e estabelecer com ele uma relação positiva, o que lhe permitiu que se identificasse com o pai e que decidisse crescer para ser como o pai, o sonho com o vampiro indica o início de um novo problema. Ele é, agora, sugado pela imagem de um masculino negativo e esta imagem, se inserirmos o sonho no contexto das narrativas e imagens produzidas no brincar na caixa de areia, parece remeter-se novamente ao pai. O vampiro introduz, desde o início, a questão da morte, do morto vivo e a de uma existência após a morte em um estado de não vida. O problema da morte, mais precisamente o do assassinato da esposa grávida, é presente na história do pai como algo esquecido, ou que quer ser esquecido, mas que existe e vem cobrar reconhecimento, sugando energia de vida na forma de um conflito difícil de ser reprimido. Esta é uma boa metáfora para a imagem do vampiro. Ele diz respeito tanto ao pai, enquanto conflito, remorso ou lembrança, quanto ao filho, enquanto mancha e barreira na identificação dele com o pai, barreira que se atualiza na medida em que o pai perpetua a atitude de violência em relação à atual esposa, mãe de Carlos.

Após o sonho, inicia-se uma nova série de brincadeiras, estórias e narrativas. A primeira narrativa organiza-se do seguinte modo, abre com uma situação inicial, na qual encontramos uma série de animais dispostos em torno de uma árvore e ao lado de uma casa, a "casa do homem”-Exposição. Então nós caçamos, matamos, castramos e colocamos os animais em jaulas - Desenvolvimento. Então os animais são soltos, mas a girafa mata todos os animais, e eles são levados de volta às jaulas para serem cuidados. Em função disso, a girafa é morta - Culminação/Peripécia. A girafa dá a luz a um filhote, então todos os animais têm filhotes. Os animais ficam presos e os filhotes soltos - Solução.

Carlos introduz o tema da morte da mãe com esta narrativa. Além deste, a narrativa apresenta, em uma forma bruta, diversos elementos que serão desenvolvidos nas estórias posteriores, como a diferença entre animais domésticos e selvagens (castrados e não castrados) ou a diferença entre a selva, a fazenda e o zoológico. Já na Exposição aparece uma oposição entre os animais que se organizam em torno das duas árvores e a casa gradeada do homem, não apenas porque a casa é colocada ao lado do cenário, mas também porque as grades nitidamente se opõem à liberdade dos animais. Se olharmos para a totalidade da narrativa, veremos que a prisão está colocada por Carlos em uma equivalência de significação com a morte e a castração. Veremos também que a violência não é uma característica exclusiva do homem ou dos homens que matam os animais, mas também da mãe, representada aqui pela girafa, com a diferença de que no final ela é morta. A solução dada por Carlos é o filho ser retirado com vida da barriga da mãe morta, bem como os filhotes permanecerem em liberdade, enquanto que os animais adultos ficam presos. Esta narrativa apresenta uma analogia estreita com a história da família de Carlos, afinal de contas seu pai matou a ex-esposa e seu irmão mais velho é filho e sobrevivente deste primeiro casamento. É difícil, portanto, pensar que tal crime seja algo realmente esquecido. Se tomarmos a presente narrativa como uma leitura de Carlos acerca deste crime, podemos supor que ele dá a ela uma tonalidade que está de acordo com a experiência de sua própria família. Isto aparece no momento em que ele representa a mãe como também sendo violenta. Este comportamento está de acordo com a forma de agir de sua própria mãe. Conforme levantamos nas entrevistas com a mãe, ela sempre brigou com o pai de Carlos com uma violência comparável à dele.

A segunda narrativa inicia com um cenário, no qual aparecem animais, um cercado, avião e tanque de guerra - Exposição. Então os soldados matam os animais e retiram filhotes da barriga deles, os quais são postos no cercado-Desenvolvimento. Então os filhotes aumentam de número e se libertam do cercado - Culminação/Peripécia. Finalmente, os soldados voltam a prender os animais em três cercados fora da caixa de areia - Solução. Após esta narrativa aparece um fragmento de narrativa ou, segundo Perroni (1992), uma protonarrativa. Nesta temos uma fazenda com um casal de porcos e filhote e uma vaca com seu filhote - Exposição. Então, os porcos são castrados - Desenvolvimento/Peripécia.

Estas narrativas são um desdobramento da primeira. Aqui, a figura da mãe violenta desaparece, e os atores que conduzem a ação passam a ser, tanto nesta como nas seguintes estórias, os homens ou os soldados. Aquela primeira estória desdobrase, também, aqui em duas. Uma passada entre animais selvagens e, como veremos nas narrativas seguintes, na selva, e outra passada na fazenda. Aqui, os animais selvagens são mortos, enquanto que os animais domésticos são castrados. 
Após esta, temos a produção de uma nova protonarrativa. Mães e filhos são colocados na caixa de areia - Exposição e, em seguida, mortos a tiros - Desenvolvimento/Peripécia.

Na próxima narrativa, mães e filhotes comem das árvores - Exposição. Então, aparecem um carro do exército e um tanque de guerra - Desenvolvimento, dos quais saem dois homens que matam todas as mães - Culminação/Peripécia. Então, os homens prendem os filhotes para levá-los ao circo - Solução.

A presente série continua na narrativa seguinte. Ela principia com uma cena, na qual aparece uma floresta com animais filhotes e adultos - Exposição. Então dois homens chegam na floresta e matam todos os animais - Desenvolvimento/Peripécia. Após a morte dos animais ocorre uma transformação na narrativa. Junto à cabana dos homens aos veículos que utilizaram para chegar à caixa de areia e matar os animais, aparece uma fazenda na qual as fêmeas são separadas dos machos para não haver briga - Solução.

Podemos pensar as narrativas de Carlos como uma tentativa de organizar sua experiência com uma família violenta e desmembrada por um assassinato e, por outro lado, de também organizar seu processo de desenvolvimento dentro desta família, o qual, como vimos acima, corre no sentido de um afastamento do universo materno, no qual ele é um bebê para a mãe, e de uma aproximação do pai e do mundo paterno, no qual ele pode vir a ser um homem. Comparando suas narrativas com sua história de vida, podemos pensar que através delas ele se pergunta o porque de a mãe de seu irmão ter sido morta, será que ela era violenta como sua mãe, será que ela cometeu um crime e teve de ser punida por ele, tal como a girafa da primeira estória? E o que aconteceu com o filho que ela carregava na barriga? Morreu também ou foi retirado e hoje é seu irmão? E o que acontece com os filhos que não têm mãe? Ficam desamparados como filhotes presos por soldados e enviados para o circo? E, principalmente, como lidar com a violência da família? Quanto a essa questão, Carlos propõe em suas estórias duas soluções. Para que a violência acabe e para que não haja brigas os animais machos devem ser separados das fềmeas. Não há uma possibilidade de união entre os sexos, se macho e fêmea, homem e mulher ou pai e mãe forem postos juntos haverá briga e continuidade da violência. Em segundo lugar, para que a violência acabe, os animais selvagens têm de se transformar em animais domésticos e, para isto, eles têm de ser castrados. A castração é uma contenção fisiológica do instinto sexual e é utilizada para tornar os animais mansos e dóceis. É também para Carlos uma ação violenta, comparada por ele à morte e ao aprisionamento. Tanto é assim, que os animais domesticados de suas fazendas aparecem, até aqui, enjaulados. Poderíamos, portanto, pensar a castração no âmbito desta família como uma repressão desse pathos, dessa paixão da ira e do poder a qual é sua principal característica. A próxima narrativa mostra que esta solução é fictícia, que ela não funcionaria.

A narrativa que dá seguimento à série tem como tema a fazenda. Parece que após todos os animais selvagens serem mortos sobra espaço apenas para os animais domesticados da fazenda. Na cena inicial aparece a fazenda, com animais domésticos, um poço e um celeiro - Exposição. Então os animais são mortos, amarrados - Desenvolvimento/Peripécia - e levados para um cercado fora da caixa de areia Solução. Ao lado do cercado, aparecem um poço e um carro do exército, elementos da fazenda e dos soldados matadores de animais.

O fato de os animais serem castrados e domesticados não os exime da violência, a domesticação, o que nesta família significa a total obediência, não aparece como uma solução para o problema da violência. A partir deste impasse, Carlos busca novamente a solução na transferência, retirando os animais de seu mundo, na caixa de areia, e trazendo-os até o meu, fora da caixa e embaixo de minha mesa de trabalho. O problema da violência apareceu na relação transferencial também sob a forma de competição. Carlos tinha de saber mais ou ser melhor. Os jogos que jogávamos tinham de ser competitivos, não havia espaço para a colaboração. É interessante ressaltar que o motivo da competição, como conteúdo das sessões e como relação de transferência, apareceu de forma significativa somente no decorrer desta série de narrativas. É interessante, também, observar que a competição resolveu-se, na transferência, imediatamente antes da seguinte narrativa, na qual o problema da violência foi aparentemente resolvido. É como se uma solução estivesse sendo gestada no processo de psicoterapia.

A próxima narrativa aparece incompleta, há uma exposição, ocorre uma ação transformadora, mas falta uma solução ou conclusão. Ela principia com um zoológico composto de animais pequenos dentro de um cercado - Exposição. Então aparecem dois homens que abrem a porteira para que os elefantes saiam - Desenvolvimento/Peripécia.

Na presente estória, não há mais a presença da selva ou da fazenda, o que temos aqui é um zoológico. Neste zoológico, os animais estão presos em um cercado, mas é um cercado diferente dos anteriores. É um cercado branco e enorme, ocupando praticamente todo o espaço da caixa de areia. Ele, além do mais, é um cercado aberto. Aqui, o homem não mata mais os animais, mas abre a porteira para que eles saiam, como se os cuidassem. Aqui, o mundo dos animais grandes é excluído. É como se não houvesse mais possibilidade de um resgate da paz, de um término da violência entre os grandes, entre os adultos. O mundo dos pais e adultos é historicamente violento, quase que naturalmente violento, portanto, um mundo sem violência terá de ser um mundo novo, construído por quem é pequeno. Não é à toa que quem sai do cercado são os elefantes, deverão ser eles o sustentáculo desse novo mundo.

\section{Conclusão}

Em suas narrativas, protonarrativas e imagens vemos Carlos tentando lidar com uma situação desfavorável de vida e procurando soluções que lhe permitam desenvolverse e crescer. Se observarmos a totalidade do material trazido pelo estudo de caso, veremos que esta produção simbólica, transcorrida dentro de um processo psicoterapêutico, teve a função de auxiliar a criança a organizar esta situação 
desfavorável de vida em uma experiência, de modo que ela seja inteligível e possível de ser transformada ou, caso isto não seja possível, para que a criança não sofra passivamente o destino que lhe é reservado pela repetição dos complexos dos pais e das famílias, e que, pela fala, através das estórias e imagens simbólicas, ela consiga, ao menos, partilhar com o terapeuta sua sina e com ele busque meios de transformá-la. O que observamos é que, através da construção das imagens e narrativas, a criança procura organizar o fluxo de acontecimentos em termos de uma experiência que faça, para ela, algum sentido, isto, de maneira que ela possa reagir a esta experiência e participar, de algum modo, na construção de sua própria vida. E a construção dessa experiência não poderia se dar de outro modo senão através de uma linguagem, seja esta lingüística, através da palavra e da narrativa ou através da imagem. Demonstramos aqui que o momento de brincar em psicoterapia é um momento de construção de um texto sobre a própria vida, seja este tex to produzido através da linguagem ou da imagem. O terapeuta é o ouvinte e o interlocutor, aquele que ao mesmo tempo escuta e que interpela a criança autora de seu texto. $\mathrm{O}$ texto produzido pela criança são as narrativas que a auxiliarão a encontrar um sentido para a sua vida, construindo, assim a sua própria representação da vida e a sua própria experiência de vida. Sem esse ato de construção de sentido, não há representação mental possível da vida, sendo esta apenas uma seqüência de eventos dos quais a criança tem pouco a ver e a dizer. É, portanto, a partir desse ato de construção de sentido que a criança ensaia uma primeira tentativa de tomar posse da própria vida, o que ocorrerá de fato somente quando se tornar adulto. De qualquer modo, o sentido deste ato é o de um impulso no desenvolvimento em direção à maturidade. É em relação a este ponto que as pesquisas de Bruner (1986/1987) oferecem uma contribuição significativa à compreensão do funcionamento da psicoterapia: o ato de construção de sentido através da narrativa oferece à pessoa elementos para que ela possa entender e transformar sua vida.

Há um outro elemento cuja presença no brincar simbólico tem, para nós, um significado fundamental: a participação da cultura através da interposição de narrativas culturalmente dadas. Pelo menos dentro do âmbito deste trabalho, podemos afirmar que sem uma referência a narrativas culturais, como os mitos e contos de fada, a compreensão do sentido das narrativas e imagens produzidas pela criança através do brincar simbólico seria uma tarefa impossível. Sem uma análise cultural do significado dos diversos animais que povoaram as estórias das crianças não conseguiríamos o nível de entendimento que apresentamos nestes estudos de caso. Sem uma referência aos estudos da crítica literária ou da mitologia, nossas interpretações não passariam de conjecturas baseadas no senso comum. Poderíamos especular sobre a natureza do leão do jacaré e do sapo ou buscar, no terreno das ciências humanas, reflexões mais bem fundamentadas. Esperamos ter demonstrado que este último caminho vale à pena ser seguido. A importância dos elementos culturais na construção de sentido nas narrativas das crianças nos faz pensar que o estudo e a interpretação do pensamento simbólico não fazem sentido senão á luz da história da humanidade. Não há como fazer uma leitura do pensamento simbólico tomando apenas o desenvolvimento ontogenético, a história de vida de uma pessoa. O pensamento simbólico só faz sentido quando o tomamos em relação à história da produção simbólica da humanidade. É somente esta comparação que revela a riqueza dos sonhos das fantasias e do brincar simbólico. Não podemos, no entanto, nos esquecer, como o fazem muitos junguianos, que sem referência à história pessoal toda a produção da imaginação não passa de infrutíferos devaneios. Este é um dos ensinamentos fundamentais de C. G. Jung. E aqui, a teoria dos arquétipos aparece como ponto de inflexão entre o individual e a produção cultural da humanidade. Ela é o construto teórico que permite relacionarmos a produção simbólica consciente e inconsciente de um indivíduo com a produção simbólica da humanidade. A teoria dos arquétipos é, portanto, uma ferramenta que permite estudar o pensamento simbólico e a produção simbólica do homem sem ter de reduzi-la a nada menos do que ela significa e sem diminuir sua grandeza de significado. A teoria dos arquétipos faz, portanto, com que uma produção simbólica individual encontre eco na produção simbólica da humanidade. O que é produzido individualmente aqui é análogo ao que é produzido coletivamente lá, e esta analogia deve-se ao fato de que somos todos humanos, de que percebemos e procuramos dar sentido ao mundo a partir de uma forma humana.

É no âmbito dessa análise histórica e cultural que poderíamos tecer uma aproximação entre a Psicologia Analítica e a Psicologia Cultural, pois, ao menos enquanto metodologia, ambas as escolas tomam o contex to histórico e cultural como base para a interpretação do dado psicológico. Em Jung, tal abordagem aparece nas diversas interpretações de sonhos, obras de arte, mitos e contos de fada trabalhados ao longo de sua obra. Em Bruner, a interpretação do psicológico à luz da história e da cultura aparece como possibilidade, através da fundamentação na Antropologia Cultural e na História Social. É no momento em que o dado psicológico é, não apenas, interpretado cultural e historicamente, mas também concebido como interpenetrado pela história e pela cultura que visualizamos uma real aproximação entre ambas.

\section{Referências}

Bruner, J. (1987). Life as narrative. Social research, 54(1), 11-32. Bruner, J. (1997). Realidade mental, mundos possiveis (M. A. G. Domingues, Trad.). Porto Alegre, RS: Artes Médicas. (Original publicado em 1986)

Chevalier, J., \& Gheerbrandt, A. (1990). Dicionário de símbolos (V. C. Silva, Trad.). Rio de Janeiro, RJ: José Olympio.

Grimm, J. (1984). The complete illustrated stories of the brothers Grimm. London: George Routledge and Sons. (Original publicado em 1853)

Jung, C. G. (1959). The psychological aspects of the kore (R. F. C. Hull, Trans.). In S. H. Read, M. Fordham \& G. Adler (Eds.), The Archetypes and the Collective Unconscious (2nd ed., Vol. 9(1), pp. 182-203). New York: Bollingen. (Original publicado em 1940) 
Jung, C. G. (1982). Aion: Estudos sobre o simbolismo do si-mesmo (M. R. Rocha, Trad.). Petrópolis, RJ: Vozes. (Original publicado em 1951)

Jung, C. G. (1984a). Instinto e inconsciente (M. R. Rocha, Trad.). In C. G. Jung. A dinâmica do inconsciente (pp. 133-142). Petrópolis, RJ: Vozes. (Original publicado em 1919)

Jung, C. G. (1984b). Aspectos gerais da psicologia do sonho (M. R. Rocha, Trad.). In A dinâmica do inconsciente (pp. 241-286). Petrópolis, RJ: Vozes. (Original publicado em 1928)

Jung, C. G. (1984c). Da essência dos sonhos (M. R. Rocha, Trad.). In $A$ dinâmica do inconsciente (pp. 287-306). Petrópolis, RJ: Vozes. (Original publicado em 1945)

Jung, C. G. (1986). Símbolos da transformação (E. Stern, Trad.). Petrópolis, RJ: Vozes. (Original publicado em 1912)

Jung, C. G. (1987). A aplicação prática da análise dos sonhos (M. L. Appy, Trad.). In Ab-reação, análise dos sonhos, transferência (pp. 11-32). Petrópolis, RJ: Vozes. (Original publicado em 1947)
Kalff, D. (1980). Sandplay: A psychotherapeutic approach to the psyche. Boston: Sigo Press.

Kant, I. (1985). Crítica da razão pura (M. P. dos Santos, Trad.). Lisboa, Portugal: Gulbenkian. (Original publicado em 1781)

Perroni, M. C. (1992). Desenvolvimento do discurso narrativo. São Paulo, SP: Martins Fontes.

Ricoeur, P. (1994). Tempo e narrativa. Campinas, SP: Papirus. (Original publicado em 1983).

Yin, R. (1994). Case study research: Design and methods. Thousand Oaks, CA: Sage
Recebido: 24/03/2005

$1^{a}$ revisão: 30/09/2005

$2^{a}$ revisão: 03/04/2006

Aceite final: 11/04/2006 